\title{
Pendekatan Sosio-Ekonomi Potensi Daerah sebagai Pusat Ekstrak Kulit Manggis di Indonesia
}

\section{Muchtaridi Muchtaridi $^{1}{ }^{*}$, Wiwit Nurhidayah ${ }^{1}$, Luthfi U. Setyawati ${ }^{1}$, Dini Rochdiani ${ }^{2}$, Risda R. Islamiaty ${ }^{1}$, Arif Budiman ${ }^{1}$}

\author{
${ }^{1}$ Departemen Analisis, Farmasi dan Kimia Medisinal, Fakultas Farmasi, Universitas Padjadjaran, \\ Bandung \\ ${ }^{2}$ Departemen Agrobisnis, Fakultas Pertanian, Universitas Padjadjaran, Bandung \\ *muchtaridi@unpad.ac.id
}

\section{Submisi: 21 Februari 2018; Penerimaan: 18 Februari 2019}

Kata Kunci: ekstrak; kulit manggis; Puspahiang; sosio-ekonomi.

ABSTRAK Salah satu daerah penghasil manggis terbesar di Kabupaten Tasikmalaya adalah Kecamatan Puspahiang, tepatnya berada di delapan desa. Petani manggis di Kecamatan Puspahiang mengandalkan kualitas ekspor karena harganya tiga kali lipat lebih mahal. Akan tetapi, karena mengejar kualitas ekspor, petani banyak membuang buah manggis yang tidak masuk kriteria kualitas ekspor, seperti buah yang terlalu kecil atau terinfeksi penyakit getah kuning. Petani harus membuang manggis yang terkena penyakit getah kuning yang parah. Selain itu, jika musim manggis berhenti, petani manggis di Puspahiang akan beralih ke mata pencaharian lain. Kulit buah manggis telah dimanfaatkan secara turun temurun oleh masyarakat sebagai obat-obatan. Penjajakan sosio-ekonomi kepada masyarakat melalui pengenalan Teknologi Tepat Guna (TTG) Ekstraksi Manggis telah dilakukan. Hal itu bertujuan untuk mengetahui respons masyarakat petani manggis di Puspahiang mengenai pengembangan Pusat Ekstrak Manggis untuk kebutuhan industri obat herbal dan nutraseutikal. Metode yang digunakan adalah metode survei, sosialisasi, serta pre-test dan post-test. Adapun data dianalisis dengan statistika deskriptif. Hasil survei sosio-ekonomi menunjukkan bahwa hampir $100 \%$ masyarakat Puspahiang setuju akan pembangunan pusat ekstraktor kulit manggis. Akan tetapi, 60\% masyarakat mengkhawatirkan masalah pengolahan limbah ekstrak.

Keywords: extract; mangosteen pericarps; Puspahiang; socio-economic.
ABSTRACT One of the largest mangosteen producing areas in Tasikmalaya Regency, which is in 8 villages in Puspahiang Sub-district. Mangosteen farmers Puspahiang district relies on export quality because the price is 3 times more expensive. However, due to farmers' pursuit of mangosteen the quality of exports of farmers will be much to remove the mangosteen fruit harvest that does not enter the quality of exports such as too small fruits or infected yellow sap disease. In addition, if the mangosteen reached in end season, mangosteen farmers in Puspahiang will switch to other livelihoods. Mangosteen pericarps has been used by generations as a medicine. Socio-economic study to community in the form of the introduction of ECO-friendly technology (TTG) Mangosteen extraction has been aimed to determine the response of mangosteen farmers in Puspahiang in the development of the Mangosteen Extract Center for the needs of the Herbal and Nutrition Medicine industries. The survey method was carried out, socialization, pre-test and post-test. Data were analyzed by descriptive statistics. The socio-economic survey showed that the Puspahiang community is almost $100 \%$ in agreement with the construction of the 
mangosteen leather extrator center. However, $60 \%$ of the public is concerned about the processing of waste extracts. Subsequently, it needs to be done waste treatment studies on the socio-economic community.

\section{PENDAHULUAN}

Jumlah produksi manggis di Indonesia mencapai 190.294 ton (Badan Pusat Statistik, 2013). Berdasarkan data 2002 hingga 2006 diketahui bahwa Indonesia telah mengekspor manggis ke Hongkong sebesar 51,2\%, 28,5\% ke China, dan lainnya ke Amerika Serikat, kawasan Timur Tengah, serta negara-negara lain di Asia. Produksi manggis di Indonesia pada 2006 berasal dari Kalimantan (2.149 ton), Sulawesi (2.894 ton), Sumatra (26.265 ton), Jawa (39.671 ton), Bali-Nusa Tenggara (1.009 ton), dan Maluku-Papua (646 ton). Produksi terbesar masih berasal dari Jawa yang meliputi Bogor (1.189 ton), Purwakarta (2.290 ton), dan Tasikmalaya (13.244 ton) (Sutrisno, E. \& Purwanto, 2009). Dinas Pertanian dan Tanaman Pangan Provinsi Jawa Barat mencatat bahwa produksi manggis terbesar di Jawa Barat dihasilkan petani asal Kabupaten Tasikmalaya, yakni sekitar 18.576 ton per tahun dari luas lahan panen sekitar 232.774 hektar. Salah satu daerah penghasil manggis terbesar di Kabupaten Tasikmalaya adalah Kecamatan Puspahiang, yakni berada di delapan desa (Diperta Jabar, 2014).

Petani manggis di Kecamatan Puspahiang mengandalkan kualitas ekspor karena harganya tiga kali lipat lebih mahal. Akan tetapi, karena mengejar manggis berkualitas ekspor, petani banyak yang membuang buah manggis hasil panen yang tidak sesuai dengan kualitas ekspor, seperti buah terlalu kecil atau terinfeksi penyakit getah kuning. Manggis yang tidak masuk kriteria ekspor tersebut akan dijual oleh petani dengan harga hingga 6000/kg ke pasar tradisional. Adapun manggis yang terkena penyakit getah kuning yang parah harus dibuang. Jika musim manggis telah selesai, petani manggis di Puspahiang akan beralih mata pencaharian.

Universitas Padjajaran telah membina Petani Puspahiang untuk menghasilkan manggis dengan kualitas ekspor. Meskipun demikian, petani manggis harus berhadapan dengan masalah ekspor Manggis. Sejak 2013, manggis yang berasal dari Indonesia tidak dapat diekspor langsung ke China, Amerika, dan Eropa, namun harus melalui Malaysia dan Thailand. Hal itu membuat dunia lebih mengenal Malaysia dan Thailand sebagai negara asal manggis meskipun jumlah ekspor manggis terbesar berasal dari Indonesia (Qosim et al., 2012). Selain itu, produksi manggis yang besar di Indonesia menyebabkan masalah limbah kulit manggis, khususnya di Kecamatan Puspahiang, Kabupaten Tasikmalaya. Hal itu disebabkan kulit manggis dianggap oleh para petani tidak memiliki manfaat sehingga tidak diolah.

Selama ini, kulit manggis dari Puspahiang telah dimanfaatkan oleh Tim Manggis Unpad sebagai bahan penelitian kesehatan. Sejak 2009, Penelitian Tim Manggis Unpad telah berhasil memanfaatkan kulit manggis untuk keperluan industri obat herbal. Tim Manggis Unpad telah mempublikasikan hasil penelitian tentang kulit manggis untuk kesehatan dan menghasilkan produk sediaan farmasi dan makanan kesehatan atau nutraseutikal (Muchtaridi, 2013; Muchtaridi et al., 2016a; Muchtaridi et al., 2016b; Muhtaridi et al., 2015). 
Terkait dengan masalah limbah kulit manggis di Kecamatan Puspahiang, Tim Manggis Unpad mencoba membangun pusat ekstrak kulit manggis di daerah tersebut untuk memberi pengetahuan kepada para petani tentang pemanfaatan kulit manggis sehingga tidak menjadi limbah, tetapi justru meningkatkan pendapatan mereka. Akan tetapi, untuk membangun pusat ekstrak kulit manggis, terlebih dahulu diperlukan penjajakakan sosioekonomi kepada masyarakat berupa pengenalan Teknologi Tepat Guna (TTG) Ekstraksi Manggis untuk kebutuhan industri (Muhtaridi et al., 2015). Melalui kegiatan Pengabdian pada Masyarakat ini akan dilakukan proses penjajakan tersebut, yakni dengan pengenalan TTG cara ekstraksi Manggis untuk kebutuhan industri obat herbal dan nutraseutikal kepada para petani manggis di Desa Puspahiang, Kecamatan Puspahiang, Kabupaten Tasikmalaya.

\section{METODE}

Penelitian ini menggunakan pendekatan kuantitatif dengan teknik penelitian survei. Penelitian dilaksanakan pada Februari s.d. Oktober 2017. Data primer diperoleh dari petani yang mengikuti sosialisasi melalui wawancara langsung dengan menggunakan kuesioner sebagai alat bantu. Adapun data sekunder diperoleh dari dinas atau intansi yang terkait dengan penelitian ini dan dari hasil penelitian sebelumnya. Penelitian dilaksanakan di Desa Puspahiang, Kecamatan Puspahiang, Kabupaten Tasikamalaya. Metode pelaksanaan program pengabdian kepada masyarakat ini terdiri atas tiga tahap, yaitu prapelaksanaan, tahap pelaksanaan, dan pascapelaksanaan.

Tahap prapelaksanaan kegiatan terdiri atas (a) survei tingkat kecamatan dan kabupaten; (b) penentuan tempat workshop TTG; dan (c) mempersiapkan alat-alat mini ekstraktor dan pelarut etanol. Adapun tahap pelaksanaan terdiri atas (a) pengisian kuesioner tentang pengetahuan ekstraksi; (b) pelaksanaan workshop TTG tentang ekstraksi; dan (c) pelaksanaan pre-test dan post-test. Tahap selanjutnya adalah pascapelaksanaan yang berupa pemonitoran dan evaluasi kegiatan. Pada tahap ini dilaksanakan pemantauan kegiatan beserta hasil-hasilnya dengan pendekatan sebelum dan sesudah, yaitu dengan melakukan hal-hal sebagai berikut.

(a) Pengisian kuesioner tentang aspek ekonomi dan sosial pengembangan pusat ekstrak kulit manggis di Puspahiang.

(b) Penjajakan kerja sama dalam program Desa Mitra antara Akademik-Pemerintah (Dinas Pertanian dan Kepala Desa)-Komunitas-Industri.

\section{HASIL DAN PEMBAHASAN}

Survei dilakukan di Kecamatan Puspahiang, Kabupaten Tasikmalaya. Pengambilan dua puluh sampel dilakukan dengan simple random sampling dari 52 populasi petani di Desa Puspahiang (lihat Tabel 1). 
Tabel 1. Karakteristik Populasi Responden di Kecamatan Puspahiang Berdasarkan Umur Responden

\begin{tabular}{cccc}
\hline No. & Umur Responden (Tahun) & Jumlah (orang) & Persentase (\%) \\
1. & $30-40$ & 3 & 15 \\
2. & $41-50$ & 4 & 20 \\
3. & $51-60$ & 11 & 55 \\
4. & $61-70$ & 2 & 10 \\
\hline Jumlah & & 20 & 100 \\
\hline
\end{tabular}

Sumber: data primer diolah (2018)

Berdasarkan Tabel 1 diketahui bahwa petani responden pada umumnya berumur antara 51-60 tahun diikuti dengan usia produktif 41-50 tahun. Pada umur tersebut, petani sudah disebut matang karena pengalaman mereka dalam bertani sesuai dengan hasil Tabel 3. Berdasarkan luas lahan diketahui bahwa rata-rata petani memiliki lahan 0,5-1 hektar dan ada 4 orang petani yang memiliki lahan di atas 1 hektar (Tabel 2.). Dalam mendukung kajian aspek ekonomi, profil responden berdasarkan jumlah tanggungan juga diidentifikasi.data Tabel 4 diperlukan untuk memutuskan responden kuesioner. Responden pada umumnya memiliki keluarga besar (50\%) dengan jumlah anak lebih dari tiga orang.

Tabel 2. Karakteristik Populasi Responden di Kecamatan Puspahiang Berdasarkan Luas

Lahan Pertanian

\begin{tabular}{cccc}
\hline No. & Luas Lahan (ha) & Jumlah (orang) & Persentase $(\%)$ \\
\hline 1. & $<0,5$ & 4 & 20 \\
2. & $0,5-1$ & 12 & 60 \\
3. & $>1$ & 4 & 20 \\
Jumlah & & 20 & 100 \\
\hline
\end{tabular}

Sumber: data primer diolah (2018)

Tabel 3 Karakteristik Populasi Berdasarkan Pengalaman Bertani Responden di

Kecamatan Puspahiang

\begin{tabular}{llll}
\hline No & $\begin{array}{c}\text { Pengalaman Berusaha } \\
\text { tani (Tahun) }\end{array}$ & Jumlah (Orang) & Persentase (\%) \\
\hline 1 & $5-10$ & 3 & 15 \\
2 & $10-15$ & 5 & 25 \\
3 & $>15$ & 12 & 60 \\
Jumlah & 20 & 100
\end{tabular}

Sumber: data primer diolah (2018)

Pada tahap pelaksanaan dilakukan workshop TTG tentang ekstrasi kulit manggis yang diikuti oleh dua puluh petani terpilih. Sebelum dan sesudah workshop, dilakukan pre-test dan post-test berdasarkan dua aspek, yaitu aspek pengetahuan ekstraksi dan aspek sosial-ekonomi pengembangan pusat ekstrak di Desa Puspahiang. Kesiapan masyarakat untuk menerapkan TTG tergantung pada indikator pengetahuan, kesiapan, dan motivasi (Nugraha \& Mahida, 
2013). Kesiapan dan motivasi dikategorikan dalam penelitian ini sebagai kajian sosial ekonomi kesiapan masyarakat.

\subsection{Penilaian Pengetahuan Petani Manggis di Kecamatan Puspahiang}

Pusat ekstrak kulit manggis dirancang untuk meningkatkan nilai ekonomi kulit manggis yang selama ini belum dimanfaatkan secara baik oleh para petani. Pembangunan pusat ekstrak ini tidak akan berjalan tanpa dukungan dan partisipasi dari para petani manggis di Kecamatan Puspahiang. Oleh karena itu, dilakukan survei dengan membagikan kuesioner kepada dua puluh orang petani manggis yang menjadi sampel di Kecamatan Puspahiang. Survei tersebut bertujuan untuk memberikan penyuluhan kepada para petani mengenai ekstrak kulit manggis dan proses ekstraksinya serta untuk mengetahui pengaruh pembangunan pusat ekstrak kulit manggis terhadap aspek sosial dan ekonomi para petani manggis. Untuk mengetahui pengetahuan dasar petani manggis mengenai ekstrak kulit manggis dan proses ekstraksi, kuesioner diberikan sebelum penyuluhan dilakukan. Kuesioner tersebut berisi beberapa pertanyaan yang mewakili indikator pengetahuan petani mengenai ekstraksi.

Tabel 4. Indikator Penilaian Pengetahuan Petani Manggis Mengenai Ekstraksi di Kecamatan Puspahiang

\begin{tabular}{clc}
\hline No. & \multicolumn{1}{c}{ Indikator } & Kisaran Skor \\
\hline 1. & Pengetahuan tentang obat tradisional & $5-10$ \\
2. & Penanganan Simplisia/bahan baku & $3-6$ \\
3. & Pemilihan Pelarut & $4-8$ \\
4. & Ekstraksi dan Cara Ekstraksi & $5-10$ \\
5. & Cara menghilangkan Pelarut & $2-4$ \\
6. & Manfaat ekstrak kulit manggis & $2-4$ \\
Jumlah & $21-42$ \\
\hline
\end{tabular}

Sumber: data primer diolah (2018)

Hasil survei pada Tabel 4 menunjukkan bahwa sebelum penyuluhan dilakukan tingkat pengetahuan petani mengenai ekstraksi masih rendah, yakni 90\%. Penyuluhan mengenai pengetahuan ekstraksi kemudian dilakukan. Penyuluhan tersebut berisi tentang penggunaan kulit manggis sebagai obat tradisional, penanganan bahan baku kulit manggis, metode ekstraksi serta pemilihan pelarut yang tepat untuk ekstraksi, dan cara menghilangkan pelarut agar mendapatkan ekstrak yang kental. Selain itu, dijelaskan pula tentang teknologi tepat guna penanganan kulit manggis untuk menghasilkan produk yang bernilai jual tinggi. Setelah penyuluhan, para petani diminta untuk mengisi kuesioner guna mengetahui tingkat kepahaman petani manggis mengenai materi penyuluhan yang diberikan. 


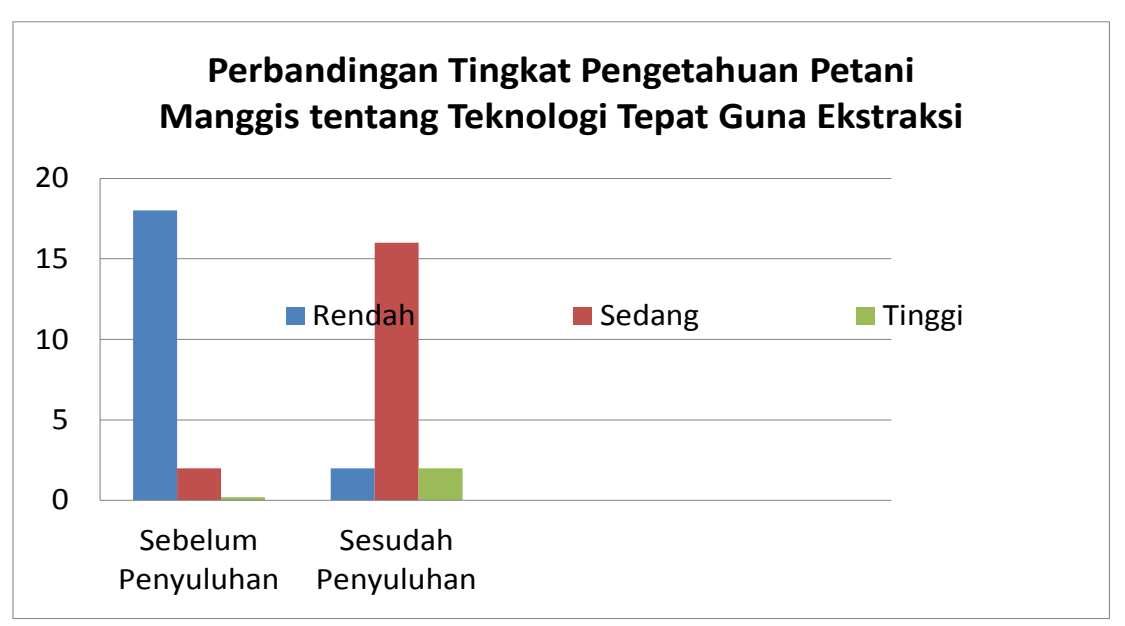

Sumber: data primer diolah (2018)

Gambar 1 Perbandingan Tingkat Pengetahuan Petani Manggis tentang Teknologi Tepat Guna Ekstraksi Sebelum dan Sesudah Penyuluhan

Gambar 1 menunjukkan bahwa pemahaman petani manggis mengenai ekstraksi meningkat setelah mengikuti penyuluhan. Dengan demikian, dapat dikatakan bahwa para petani akan mampu mengelola pusat ekstrak kulit manggis. Akan tetapi, dalam pengelolaan tersebut tetap diperlukan bimbingan dan pendampingan dari pihak Universitas Padjadjaran.

\subsection{Penilaian Sosial Ekonomi Petani Manggis di Kecamatan Puspahiang}

Pengembangan pusat ekstrak kulit manggis akan berdampak pada kehidupan sosial dan ekonomi para petani manggis di Kecamatan Puspahiang, Kabupaten Tasikmalaya. Oleh karena itu, perlu dilakukan pengkajian tentang seberapa besar perubahan aspek sosial ekonomi yang terjadi sebagai pertimbangan dalam pembangunan pusat ekstrak kulit manggis. Untuk mengetahui perubahan aspek sosial dan ekonomi yang akan terjadi, para petani manggis diminta untuk mengisi kuesioner. Dalam aspek ekonomi, pembangunan pusat ekstrak kulit manggis diharapkan akan dapat meningkatkan pendapatan petani dan mempermudah proses pemasaran serta manajemen pascaproduksi. Dengan demikian, para petani memerlukan bantuan berupa biaya produksi, pengoperasian serta instalasi alat, dan dukungan pemerintah daerah dalam pembangunan pusat ekstrak kulit manggis tersebut.

Tabel 5. Indikator Penilaian Aspek Ekonomi

\begin{tabular}{clc}
\hline No. & \multicolumn{1}{c}{ Indikator } & Kisaran Skor \\
\hline 1. & Biaya Produksi & $3-6$ \\
2. & Peningkatan pendapatan & $4-8$ \\
3. & Manajemen pengoperasian dan instalasi alat & $3-6$ \\
4. & Pemasaran hasil produksi & $3-6$ \\
5. & Dukungan Pemda/Aspek legal & $2-4$ \\
6. & Manajemen pasca produksi & $2-4$ \\
Jumlah & $17-34$ \\
\hline
\end{tabular}

Sumber: data primer diolah (2018) 
Tabel 6. Hasil Penilaian Aspek Ekonomi Pusat Ekstrak Kulit Manggis

\begin{tabular}{clccc}
\hline No. & $\begin{array}{c}\text { Tingkat Penilaian } \\
\text { Petani }\end{array}$ & Skor & $\begin{array}{c}\text { Jumlah } \\
\text { (orang) }\end{array}$ & $\begin{array}{c}\text { Persentase } \\
(\%)\end{array}$ \\
\hline 1. & Rendah & $17 \leq \mathrm{E} \leq 22,67$ & 3 & 15 \\
2. Sedang & $22,67 \leq \mathrm{E} \leq 28,33$ & 15 & 75 \\
3. Tinggi & $28,33 \leq \mathrm{E} \leq 33,67$ & 2 & 10 \\
Jumlah & & 20 & 100 \\
\hline Sumber: data primer diolah (2018) & &
\end{tabular}

Berdasarkan data di atas diketahui bahwa pengembangan pusat ekstrak kulit manggis akan berdampak positif terhadap aspek ekonomi petani manggis di Puspahiang. Selain aspek ekonomi, dampak sosial dari adanya pusat ekstrak kulit manggis juga perlu diperhatikan. Hal itu disebabkan pusat ekstrak kulit manggis berpengaruh terhadap penyerapan tenaga kerja dan keterlibatan masyarakat yang memungkinkan timbulnya kecemburuan sosial dan perubahan struktur pekerjaan masyarakat Puspahiang.

Tabel 7. Indikator Penilaian Aspek Sosial

\begin{tabular}{clc}
\hline No. & \multicolumn{1}{c}{ Indikator } & Kisaran Skor \\
\hline 1. & Penyerapan Tenaga Kerja & $3-6$ \\
2. & Keterlibatan Masyarakat & $3-6$ \\
3. & Dukungan Pemerintah/Pembinaan & $3-6$ \\
4. & Kecemburuan social & $4-8$ \\
5. & Penanganan Limbah & $5-10$ \\
6. & Perubahan struktur pekerjaan & $4-8$ \\
Jumlah & & $22-44$ \\
\hline
\end{tabular}

Sumber: data primer diolah (2018)

Tabel 8. Hasil Penilaian Aspek Sosial

\begin{tabular}{clccc}
\hline No. & Tingkat Partisipasi Petani & Nilai & $\begin{array}{c}\text { Jumlah } \\
\text { (orang) }\end{array}$ & $\begin{array}{c}\text { Persentase } \\
(\%)\end{array}$ \\
\hline 1. Rendah & $22 \leq \mathrm{S} \leq 28,67$ & 7 & 35 \\
2. Sedang & $28,67 \leq \mathrm{S} \leq 35,33$ & 9 & 45 \\
3. Tinggi & $35,33 \leq \mathrm{S} \leq 43,67$ & 4 & 20 \\
Jumlah & & 20 & 100 \\
\hline
\end{tabular}

Sumber: data primer diolah (2018)

Pusat ekstrak kulit manggis diharapkan tidak berdampak negatif terhadap aspek sosial. Apabila lebih dari 50\% populasi petani mendapat hasil yang tinggi, pembangunan pusat ekstrak kulit manggis akan dipertimbangkan untuk tidak jadi dilakukan. Terkait hal tersebut, hasil survei menunjukkan bahwa hanya $20 \%$ petani yang memiliki nilai tinggi pada aspek sosial sehingga pembangunan pusat ekstrak kulit manggis dapat dilakukan. Akan tetapi, berdasarkan skor pertanyaan mengenai penanganan limbah, yakni kisaran 5-10 diketahui bahwa petani masih mengkhawatirkan perihal penanganan limbah. Solusi untuk 
masalah tersebut (lihat Gambar 2.) adalah perlunya sinergisme antara lima komponen pentaheliks (Maghfiro, Saleh, \& Rozikin, 2013).

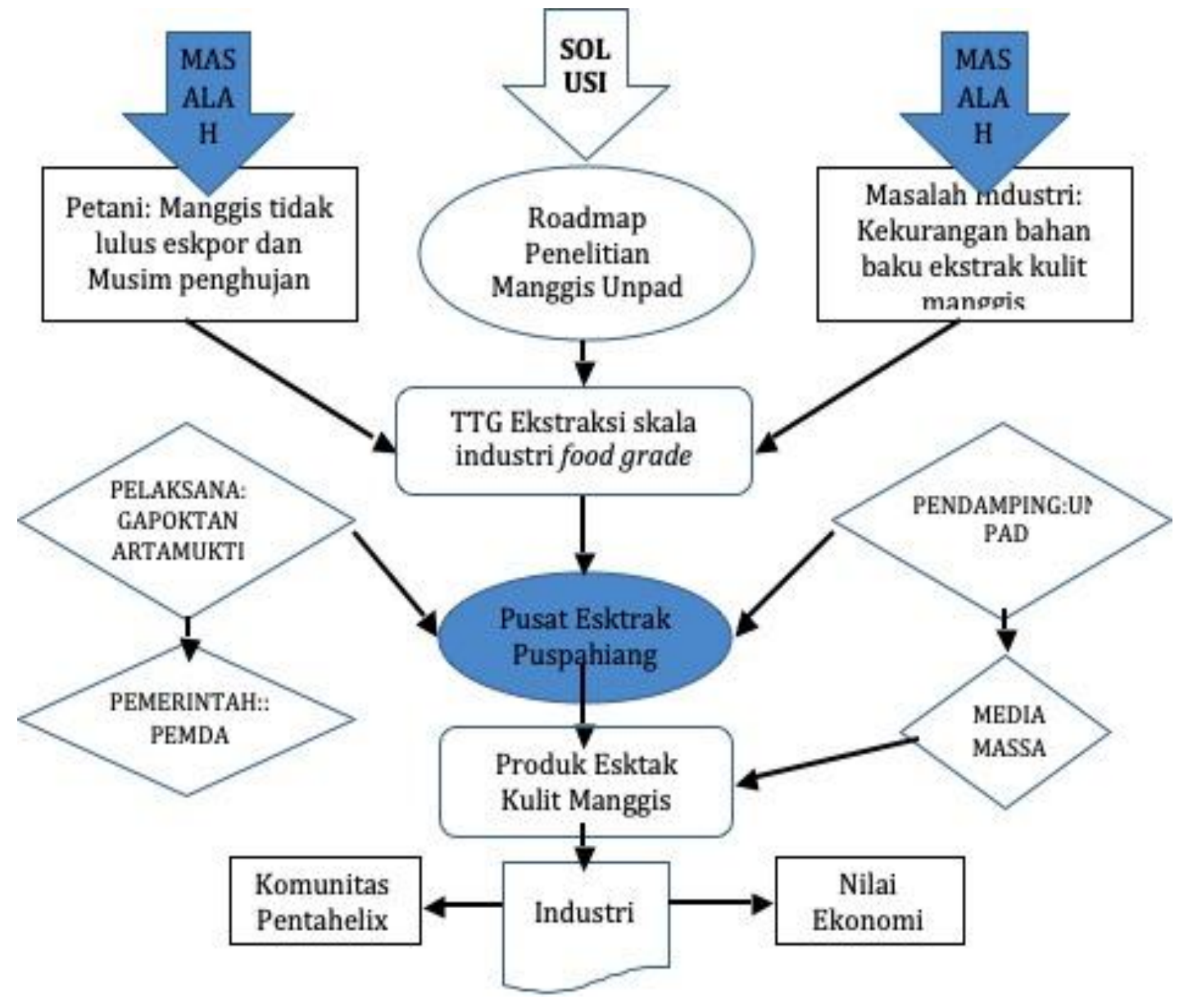

Sumber: data primer diolah (2018)

Gambar 2. Alur Solusi yang Ditawarkan pada Pengembangan Pusat Ekstrak Kulit Manggis di Puspahiang pada Tahap Selanjutnya

\section{SIMPULAN}

Berdasarkan kajian sosio-ekonomi diketahui bahwa hampir 100\% masyarakat Desa Puspahiang menyetujui pembangunan pusat ekstrator kulit manggis. Namun, 60\% masyarakat mengkhawatirkan masalah pengolahan limbah ekstrak. Penelitian selanjutnya dapat dilakukan untuk mengkaji masalah pengaruh pengolahan limbah terhadap aspek sosioekonomi masyarakat.

Pascapelaksanaan dilakukan penjajakan kerja sama antara akademik (Unpad), pemda (Dinas Petanian/Kepala Desa), komunitas (Gapoktan), dan industri untuk mengidentifikasi penyelesaian masalah pada program selanjutnya. Penyelesaian masalah diidentifikasi berdasarkan dua hal, yakni (a) penyelesaiaan masalah petani manggis dan (b) penyelesaian masalah industri. Berdasarkan dua masalah tersebut kemudian ditawarkan solusi kepada masyarakat petani dan pengumpul manggis, yaitu pengenalan Teknologi Tepat Guna Ekstraksi untuk memanfaatkan kulit manggis yang jika dijual harganya murah. 
Teknologi Tepat Guna yang diperkenalkan berupa alat ekstraktor skala industri dengan vakum bertekanan. Alat ini juga didukung dengan teknologi pengeringan dan penguapan pelarut yang terintegrasi saat produksi. Alat ini akan diintroduksi kepada masyarakat Desa Puspahiang. Penggunaannya didampingi hingga mereka mampu menghasilkan pendapatan yang lebih baik, terutama untuk biaya perawatan alat ekstraktor dan kelengkapnnya.

Berdasarkan dampak dari pelaksanaan ini kemudian dilakukkan rekayasa sosial berupa pelatihan-pelatihan rutin per dua bulan agar masyarakat tidak canggung dengan teknologi ini. Pelatihan tersebut dilaksanakan secara langsung melalui Program Profesor Masuk Desa dengan dana pendampingan dari Unpad (10\%). Proses ini diharapkan akan menghasilkan luaran nyata yaitu: (1) Produk ekstrak bernilai ekonomis yang pada tahun keempat akan dipasarkan; dan (2) Komunitas Pentaheliks Manggis antara akademik (Unpad), pemerintah (Pemda), industri (PT. Kimia Farma, Tbk), komunitas (Gapoktan Artamukti), dan media masa (Pikiran Rakyat).

\section{DAFTAR PUSTAKA}

Badan Pusat Statistik. (2013). Statistik Tanaman Buah-Buahan dan Sayuran Tahunan Indonesia. Retrieved from https://www.bps.go.id/linkTabelStatis/view/id/1021

Diperta Jabar. (2014). Wilayah Sentra dan Produksi Buah Tahun 2011. Retrieved from http://diperta.jabarprov.go.id/index

Maghfiro, I., Saleh, M. S., \& Rozikin, M. (2013). Analisis Peran Pemerintah dalam Mengatasi Limbah Industri Pabrik Gula Tjoekir. J. Admin. Pub.(3), 94-102.

Muchtaridi, M. (2013). Computer-aided Drug Design of Potential Neuraminidase Inhibitors from Plant Extracts: Universiti Sains Malaysia.

Muchtaridi, M. et al. (2016a). Pengembangan Obat Anti Virus Flu Burung dari Ekstrak Kulit Buah Manggis dan Buah Asam Keping Melalui Penghambatan Reseptor Neuraminidase. Laporan Akhir PUPT.

Muchtaridi, M. et al. (2016b). Quantitative Analysis of A-mangostin in Mangosteen (Garcinia mangostana L.) Pericarp Extract from Four District of West Java by HPLC Method. Int. J. Pharmaceu. Pharm. Sci., 8(8), 232-236.

Muchtaridi, M. et al. (2018). Pengembangan Pusat Ekstrak Kulit Manggis Jawa Barat di Desa Puspahiang Kabupaten Tasikmalaya untuk Kebutuhan Industri Obat Herbal Indonesia. Retrieved from Jatinangor: Laporan Akhir Program Pengembangan Desa Mitra. Ristek-Dikti. Jatinangor.

Muhtaridi, M. et al. (2015). Produksi Isolat Gartanin dari Kulit Buah Manggis. 
Nugraha, D. \& Mahida, M. (2013). Community Readiness in the Application of Technology of Drinking Water Treatment (Case Study: Palu'e Island, Nusa Tenggara Timur) $J$. Sosek Pekerjaan Umum, 5(2), 76-139.

Qosim, W. A. et al. (2012). Aplikasi Teknologi Pembibitan pada Manggis di Desa/ Kecamatan Puspahiang, Kabupaten Tasikmalaya. Dharmakarya, 1(2), 94-99.

Sutrisno, E. \& Purwanto, Y. A. (2009). Implementasi Penelitian Penanganan Pascapanen Manggis untuk Mendukung Program Integrated Supply Chain Management of Exotic Fruits From The ASEAN Region. Paper presented at the Seminar Hasil Hasil Penelitian IPB 2009, Bogor. 